\section{OWL AND DUCK NEST CLOSE TOGETHER}

Mrs. RETA BARR, Davidson, Saskatchewan, SOG $1 A 0$.

My husband, George Barr, while summerfallowing near Davidson, Saskatchewan, in the spring of 1977 , found an owl nest and a duck nest close together on the ground. Having seen them in time, he swung the cultivator widely to the side, leaving a good-sized area with cover. He hoped the crows would not notice.

We went almost daily to follow progress, standing on the truck box at a distance. The photograph was obtained in this way, when the first two Short-eared Owls had hatched in the nest in the foreground. Owls begin to incubate as soon as they lay one egg, so their young do not hatch at the same time.

I was the one summerfallowing on the day the ducklings hatched, and the duck was ready to take them to a nearby slough. The owl sat at her nest and paid no attention but crows flew by and spotted the ducklings. I just worked round and round and kept the crows from landing until the mother duck and her ducklings arrived safely at the slough.

The little owls grew daily and stayed in the area for some time.

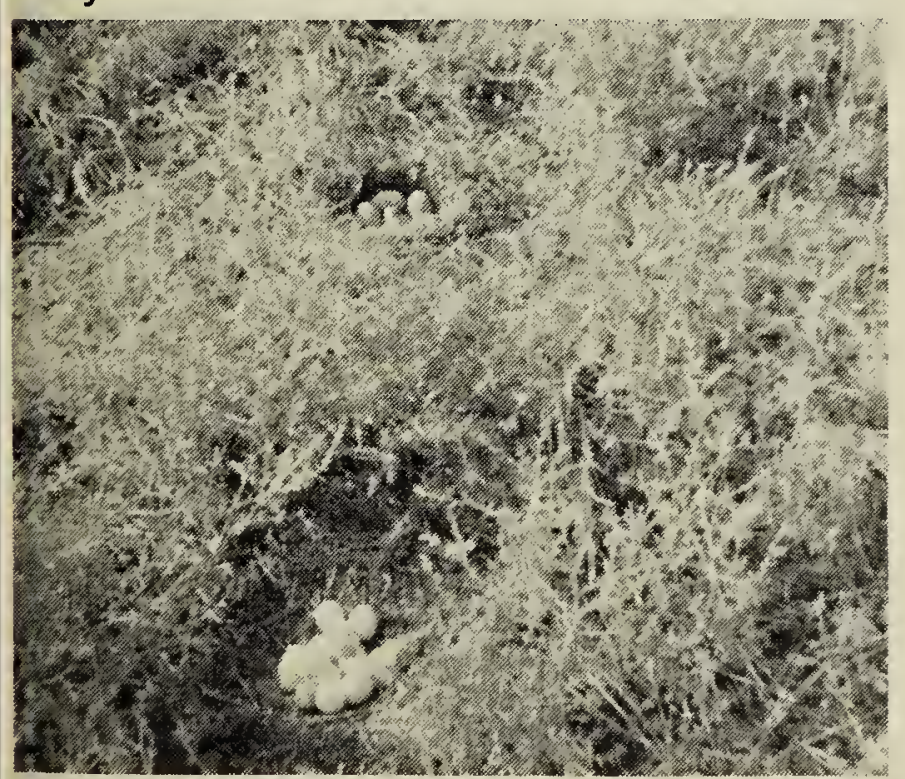

Owl's nest and duck's nest.

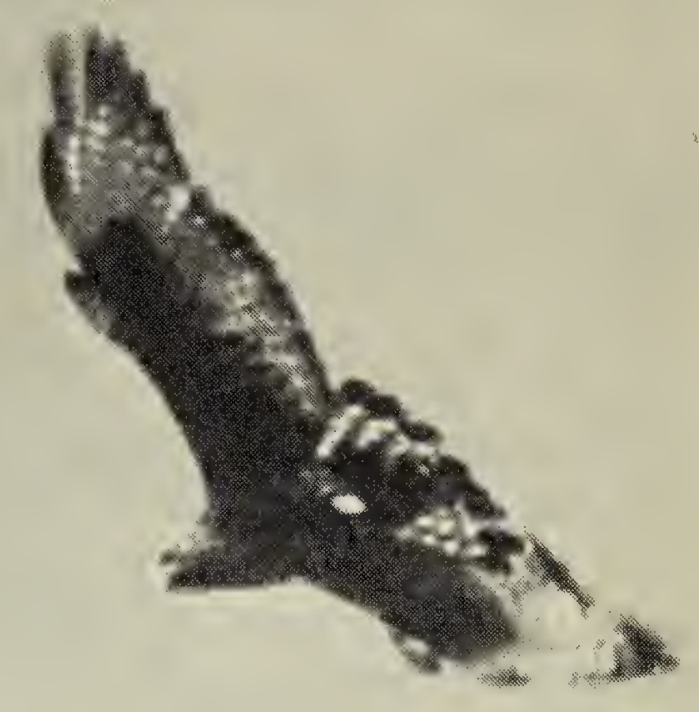

Rough-legged Hawk

M.A. Gollop

\section{ROUGH-LEGGED HAWK PREDATION ON SHARP. SHINNED HAWK}

GENE COLLINS, Department of Mines, Natural Resources and Environment, 1495 St. James Street, and ROBERT BIRD, 529 Mark Pearce, Winnipeg, Manitoba.

About 1500 on 15 September 1979 , we observed an incident of predation by a Rough-legged Hawk on a Sharpshinned Hawk in the Pembina Valley, 17 miles west of Pilot Mound, in southwestern Manitoba. Although we did not see the Rough-leg strike the Sharp-shin, we saw the larger bird sitting on it along a road allowance. As we approached, the Rough-leg tried unsuccessfully to fly off with its prey. We found the Sharp-shin bleeding from the back of the skull and in the last throes of dying.

We left the dead bird and came back one-half hour later to discover that the Rough-leg had returned and had torn the feathers off the back of its victim. We did not disturb the dead bird and left the area. 